\title{
Hubungan Profil Lipid Terhadap Kontrol Glikemik DM Tipe 2 Peserta Program Pengelolaan Penyakit Kronis (Prolanis) di fasilitas Kesehatan Provinsi Lampung Tahun 2021
}

\author{
Suyatno $^{1}$, Betta Kurniawan ${ }^{2}$, Suharmanto ${ }^{2}$ \\ ${ }^{1}$ Mahasiswa Program Studi Magister Kesehatan Masyarakat Fakultas Kedokteran Universitas Lampung \\ ${ }^{2}$ Dosen Program Studi Magister Kesehatan Masyarakat Fakultas Kedokteran Universitas Lampung
}

\begin{abstract}
Abstrak
Diabetes Melitus (DM) masih menjadi permasalahan dunia. International Diabetes Federation (IDF) memperkirakan ada peningkatan prevalensi DM di tahun 2030 sebanyak 576 juta orang, dan meningkat menjadi 700 juta pada tahun 2045. Menurut Organisasi Kesehatan Dunia (WHO) DM dapat menyebabkan kecacatan dan kematian secara dini. Faktor resiko pada DM diantaranya adalah karteristik dan profil lipid. Tujuan penelitian untuk mengetahui korelasi karketeristik dan kadar lipemik dengan penyakit Diabetes Melitus peserta prolanis. Rancangan penelitian adalah analitik dengan pendekatan crosssectional. Sampel adalah pasien DM dengan pemeriksaan HbA1C dan profil Lipid pada priode bulan Februari sampai Maret tahun 2021. Analisa univariat untuk melihat distribusi frekuensi karakteristik, status kontrol Diabetes Melitus, status kadar kholesterol, Trigliserida, HDL dan LDL. Uji penelitian didapatkan rata-rata responden berumur 51-60 tahun, perempuan, dari perkotaan. Rata-rata kadar HbA1C 8,67, Kholesterol 210,82, trigliserida 178,19, HDL 94 dan LDL 125,55. Dari uji bivariat menunjukan terdapat hubungan yang bermakna antara kontrol glikemik dengan kadar trigliserida dengan $\mathrm{p}$ value $=0,000$, namun tidak bermakna dengan profil lipid yang lain. Peningkatan trigliserida erat kaitannya dengan kebisaaan pola makanan. gaya hidup sehat dapat mengurangi terjadinya DM
\end{abstract}

Kata Kunci : Diabetes Melitus, HbA1C, Profil lipid

\section{The Relationship of Lipid Profiles to Glycemic Control of Type 2 DM Participants in the Chronic Disease Management Program (Prolanis) in Lampung Provincial Health Facilities in 2021}

\begin{abstract}
Diabetes Mellitus is still a world problem. The International Diabetes Federation estimates there will be an increase in the prevalence of DM in 2030 by 576 million people, and an increase to 700 million in 2045. According to the World Health Organization DM can cause disability and premature death. Risk factors for DM include carteristik and lipid profile. The aim of the study was to determine the correlation between carieristic and lipemic levels with Diabetes Mellitus in prolanis participants. The research design was analytic with a crosssectional approach. Samples were DM patients with HbA1C examination and Lipid profiles in the period February to March 2021. Univariate analysis to see the characteristic frequency distribution, control status of Diabetes Mellitus, status of cholesterol levels, triglycerides, HDL and LDL. The research test found that the average respondent was 51-60 years old, female, from urban areas. The average HbA1C levels were 8.67, cholesterol 210.82, triglycerides 178.19, HDL 94 and LDL 125.55. Bivariate test showed there was a significant relationship between glycemic control and triglyceride levels with $\mathrm{p}$ value $=0.000$, but it was not significant with other lipid profiles. Triglycerides is related to the diet. a healthy lifestyle can reduce the incidence of DM
\end{abstract}

Keywords: : Diabetes Mellitus, HbA1C, Lipid profile

Korespondensi: Suyatno, Program Studi Magister Kesehatan Masyarakat Fakultas Kedokteran Universitas Lampung, Jalan Sumantri Brojonegoro No. 1 Bandar Lampung, mobile 08127901078, e-mail suyatnopramitra@gmail.com 


\section{Pendahuluan}

Diabetes Melitus (DM) adalah salah satu penyakit tidak menular dan bersifat kronis, DM diakibatkan karena ketidakmampuan pankreas memproduksi hormon insulin, atau insulin yang diproduksi tidak mampu diguakan oleh tubuh secara efektif (WHO, 2016)

Berdasarkan estimasi yang dikeluarkan oleh pusat data dan informasi kementerian kesehatan Republik Indonesia tahun 2020, bahwa jumlah penderita DM di sepuluh besar negara dengan jumlah penderita DM terbanyak pada tahun 2000 dan 2030 mencatat bahwa indonesia menduduki peringkat ke 4 jumlah penderita DM dibawah Amerika Serikat, Cina dan India.

Berdasarkan hasil Riset Kesehatan Dasar (Riskesdas) tahun 2018, proporsi gula darah puasa terganggu berdasarkan pemeriksaan gula darah pada penduduk usia $\geq 15$ tahun menurut karaketristik sebanyak 26,3\%, sedangkan proporsi toleransi glukosa terganggu berdasarkan pemeriksaan gula darah mencapai 30,8\% (Kemenkes, 2018a)

Berdasarkan Riskesdas Tahun 2018, prevalensi DM yang didiagnosa dokter pada penduduk umur $\geq 15$ Tahun di Propinsi Lampung adalah sebesar $1,37 \%$ dari jumlah penduduk di propinsi lampung pada 15 kabupaten kota di propinsi lampung (Kemenkes, 2018b)

Pengelolaan DM yang buruk akan berdampak pada beberapa komplikasi, glukosa darah tinggi dapat memicu terjadinya ketoasidosis diabetikum (DKA) hingga kematian, sedangkan gula darah yang rendah dapat menyebabkan kejang atau kehilangan kesadaran (WHO, 2016).

Penyakit DM khususnya DM tipe 2 berakitan erat dengan gangguan metabolisme dalam tubuh, baik pada pancreas, otot, usus, terutama pada sel lemak yang dapat menyebabkan lipolisis meningkat dan lipoginesis menurun (Drecoli, 2019). Peningkatan lipolisis akan memicu terjadinya glucotoxicity disertai lipotoxicity yang menyebabkan terjadinya peningkatan kadar LDL kolesterol. Dalam keadaan hipergikemia, oksidasi LDL berlangsung lebih cepat. (Rahayu, 2020)

Pemeriksaan gula darah dan HbAlc saling melengkapi dalam memberikan infomasi dalam menilai status glikemik, HbA1c juga digunakan sebagai gold standar sebagai kontrol baik buruknya mengelolaan Diabetes Melitus (Indranila, 2017)
Pemeriksaan HbA1c dilakukan untuk memantau kontrol jangka panjang seseorang dengan penyakit DM. Hal ini dikarenakan bahwa sel darah merah di dalam tubuh yang sudah berikatan dengan glukosa dapat bertahan selama 2 sampai 3 bulan, ada pula yang berpendapat hingga 120 hari. Oleh karena itu, hemoglobin yang terglikosilasi dapat menunjukkan tingkat glukosa darah seseorang sekitar 3 bulan, sehingga pemantauan yang paling tepat untuk penderita diabetes adalah melakukan pemeriksaan HbA1c (Irmayanti, et all, 2018).

Azmi (2014) dalam penelitiannya bahwa orang dengan usia lebih dari 45 tahun bersiko 1,690 kali lebih beresiko mengalami kejadian DM. Irmayanti (2018) menyatakan bahwa faktor usia dan jenis kelamin berhubangan Hba1c. Budiman (2015) dalam penelitiannya bahwa penyakit diabetes melitus ini juga merupakan salah satu penyakit yang lebih banyak diderita oleh pasien dengan riwayat dislipidemia. Rahayu (2020) dalam penelitiannya mendapatkan ada hubungan yang signifikan antara gula darah puasa dengan kadar trigliserida. Tujuan penelitian untuk mengetahui korelasi karketeristik dan kadar lipemik dengan penyakit Diabetes Melitus peserta prolanis

\section{Metode}

$\begin{array}{lrrr}\text { Penelitian ini } & \text { merupakan rancangan } \\ \text { penelitian dengan pendekatan } & \text { studi } \\ \text { crosssectional yang } & \text { bertujuan untuk }\end{array}$ mengidentifikasi ada atau tidaknya hubungan pada variabel yang diukur, waktu penelitian dilakukan pada bulan April 2021 di Laboratorium Pramitra Biolab Indonesia, Populasi target dalam penelitian ini adalah penderita DM tipe 2. Pengambilan sampel dengan teknik total sampling, sehingga sampel penelitian sama dengan populasi penelitian, jumlah sampel pada penelitian ini sebesar 350 sampel. Sampel yang diambil adalah data primer pada peserta prolanis yang melakukan pemeriksaan Hbalc dan profil Lipid (Kholesterol Total, Trigliserida, HDL dan LDL) pada priode bulan Februari sampai Maret tahun 2021 di Laboratorium Klinik Pramitra biolab Indonesia.

Sampel diperiksa untuk HbA1c adalah darah EDTA menggunakan alat fotometri full automatik mengunakan reagen paket $\mathrm{HbAlc}$ serta metode yang digunakan adalah Nephelometri dan turbidimietry dan telah terstandarsasi NGSP (National Glycohematologin Standarization Program) 
hasil pemeriksaan dinyatakan dalam \%. Sampel pemeriksaan profil lipid adalah serum darah puasa, menggunakan alat chemstry analizer full automatic dengan metode enzimetik.

Teknik Pengumpulan data dilakukan dengan mencatat data karakteristik pasien DM tipe 2 yang melakukan pemeriksaan Hba1c dan

profil lipid di Laboratorium Pramitra Biolab Indonesia. Analisa data univariat adalah memberikan gambaran distribusi penyakit DM Tipe 2 berdasarkan Karakeristrik responden, Kadar HbA1c dan Profil lipid. Analisa bivariat dilakukan untuk menganalisis hubungan antara kontrol glikemik DM tipe 2 berdasarkan pemeriksaan HbA1c dengan interpretasi Profil lipid berdasarkan pemeriksaan profil lipid, dengan menggunakan uji statistik korelasi pearson. Uji korelasi juga untuk mengetahui kekuatan dan arah hubungan dan arah hubungan antara status DM tipe 2 dengan inetrpretasi kadar profil lipid.

\section{Hasil}

Hasil penelitian dikelompokan pada beberapa pengolahan data yang meliputi

A. Kadar HbA1c, Profil Lipid

Berdasarkan hasil pengumpulan data pada 350 orang, didapatkan data yang disajikan dalam tabel berikut ini:

Tabel 1. Nilai Rata-Rata, Standar Deviasi Hasil Pengukuran

\begin{tabular}{lcccc}
\hline \multicolumn{1}{c}{ Variabel } & Min & Max & Mean & SD \\
\hline Kadar HbA1c & 3,00 & 15,00 & 8,67 & 2,5 \\
Kolesterol & 98 & 566,00 & 210,82 & 49,9 \\
Trigliserida & 39,00 & 887,00 & 178,19 & 111,6 \\
HDL & 18,00 & 94,00 & 58,81 & 12,8 \\
LDL & 48,00 & 287,00 & 125,55 & 34,5 \\
\hline
\end{tabular}

Hasil pengukuran kadar Kadar HbA1c berdasarkan National Glycohemoglobin Standardization Program (NGSP) didapatkan nilai paling kecil 3,00 dan nilai paling besar 15,00 , sedangkan nilai rata-rata 8,67 dan standar deviasi 2,4. Pengukuran kadar kolesterol didapatkan nilai paling kecil 98,00 dan nilai paling besar 566,00 , sedangkan nilai rata-rata 210,82 dan standar deviasi 49,9. Pengukuran kadar trigliserida didapatkan nilai paling kecil 39,00 dan nilai paling besar 887,00, sedangkan nilai rata-rata 178,19 dan standar deviasi 111,6. Pengukuran kadar HDL didapatkan nilai paling kecil 18,00 dan nilai paling besar 94, sedangkan nilai rata-rata 55,81 dan standar deviasi 12,9. Pengukuran kadar LDL didapatkan nilai paling kecil 48,00 dan nilai paling besar 287,00 , sedangkan nilai ratarata 125,55 dan standar deviasi 34,3 .

Tabel 2. Distribusi Frekuensi Berdasarkan karteristik, kontrol glikemik tipe 2 dan intepretasi profil lipid

\begin{tabular}{|c|c|c|c|}
\hline Variabel & Kategori & $\mathrm{F}$ & $\%$ \\
\hline \multicolumn{4}{|l|}{ Umur } \\
\hline & 30-40 tahun & 11 & 3,1 \\
\hline & 41-50 tahun & 59 & 16,9 \\
\hline & 51-60 tahun & 128 & 36,6 \\
\hline & $61-70$ tahun & 122 & 34,9 \\
\hline & $>70$ tahun & 30 & 8,9 \\
\hline \multicolumn{4}{|l|}{ Jenis Kelamin } \\
\hline & Laki-laki & 93 & 26,6 \\
\hline & Perempuan & 257 & 73,4 \\
\hline \multirow{2}{*}{ Asal } & & 215 & 61,4 \\
\hline & $\begin{array}{l}\text { Kota } \\
\text { Kabupaten }\end{array}$ & 132 & 38,6 \\
\hline \multicolumn{4}{|l|}{$\begin{array}{l}\text { Kadar HbA1c } \\
\text { (NGSP) }\end{array}$} \\
\hline & Normal & 36 & 10,3 \\
\hline & Pre Diabetes & 92 & 26,3 \\
\hline & Diabetes & 222 & 63,4 \\
\hline \multicolumn{4}{|c|}{ Kadar Kolesterol } \\
\hline & Normal & 151 & 43,1 \\
\hline & Tidak Normal & 199 & 56,9 \\
\hline \multicolumn{4}{|c|}{ Kadar Trigliserida } \\
\hline & Normal & 183 & 52,3 \\
\hline & Tidak Normal & 167 & 47,7 \\
\hline \multirow{2}{*}{\multicolumn{4}{|c|}{$\begin{array}{l}\text { Kadar High Density } \\
\text { Lipid (HDL) }\end{array}$}} \\
\hline & & & \\
\hline & Normal & 302 & 86,3 \\
\hline & Tidak Normal & 48 & 13,7 \\
\hline \multicolumn{4}{|c|}{$\begin{array}{l}\text { Kadar Low Density } \\
\text { Lipid (LDL) }\end{array}$} \\
\hline Lipid (LDL) & Normal & 291 & 83,1 \\
\hline & Tidak Normal & 59 & 16,9 \\
\hline Total & & 350 & 100,0 \\
\hline
\end{tabular}

Hasil pengukuran mendapatkan bahwa sebagian besar responden adalah umur 51-60 tahun, perempuan, asal kota, dalam kondisi gula darah tinggi, kadar kolesterol tidak normal, kadar trigliserida normal, kadar HDL normal, dan kadar LDL normal.

A. Hubungan Antar Variabel dengan Kadar HbA1c (NGSP)

Pada tabel 3 Hasil analisis didapatkan bahwa sebagian besar responden yang mempunyai nilai HbA1c berdasarkan NGSP dalam kategori normal adalah usia 61-70 tahun, sedangkan yang paling banyak pada kategori pre diabetes adalah usia 60-70 tahun, sedangkan yang paling banyak pada kategori diabetes adalah usia 51-60 tahun. 
Hubungan antar variabel dengan kadar HbA1c (NGSP) dapat digambarkan pada tabel dibawah ini :

Tabel 3. Hubungan Antara Umur dengan Kontrol glikemik DM Tipe 2 berdasarkan pemeriksaan Kadar HbA1c (NGSP)

\begin{tabular}{|c|c|c|c|c|c|}
\hline \multirow{2}{*}{ Umur } & \multicolumn{3}{|c|}{ Kadar HbA1c (NGSP) } & \multirow{2}{*}{ Total } & \multirow{2}{*}{$\mathrm{p}$} \\
\hline & baik & Sedang & Buruk & & \\
\hline \multirow{2}{*}{ 30-40 tahun } & 2 & 1 & 8 & 9 & 0,09 \\
\hline & $18,2 \%$ & $9,1 \%$ & $72,7 \%$ & $100 \%$ & \\
\hline \multirow{2}{*}{ 41-50 tahun } & 6 & 12 & 41 & 59 & \\
\hline & $10,2 \%$ & $20,3 \%$ & $69,5 \%$ & $100 \%$ & \\
\hline \multirow{2}{*}{ 51-60 tahun } & 11 & 27 & 90 & 128 & \\
\hline & $8,6 \%$ & $21,1 \%$ & $70,3 \%$ & $100 \%$ & \\
\hline \multirow{2}{*}{$61-70$ tahun } & 15 & 39 & 68 & 124 & \\
\hline & $12,3 \%$ & $32,0 \%$ & $55,7 \%$ & $100 \%$ & \\
\hline \multirow{2}{*}{$71-80$ tahun } & 2 & 13 & 15 & 30 & \\
\hline & $6,7 \%$ & $43,3 \%$ & $50,0 \%$ & $100 \%$ & \\
\hline \multirow{2}{*}{ Total } & 36 & 92 & 222 & 350 & \\
\hline & $10,3 \%$ & $26,3 \%$ & $63,4 \%$ & $100 \%$ & \\
\hline
\end{tabular}

Analisis lanjut mendapatkan $\mathrm{p}=0,09$ yang berarti bahwa tidak ada hubungan antara umur dengan kontrol glimek DM tipe 2 dari nilai HbA1c berdasarkan NGSP

Pada tabel 4 Hasil analisis mendapatkan bahwa sebagian besar responden dengan pengelolaan kontrol glikemik baik adalah perempuan, sedangkan yang paling banyak pada kategori sedang adalah laki-laki, sedangkan dengan kontrol buruk adalah perempuan

Tabel 4. Hubungan Antara Jenis Kelamin dengan kontrol glikemik DM tipe 2 berdasarkan pemeriksaan Kadar HbA1c (NGSP)

\begin{tabular}{cccccc}
\hline \multirow{2}{*}{$\begin{array}{c}\text { Jenis } \\
\text { Kelamin }\end{array}$} & \multicolumn{2}{c}{ kadar HbA1c (NGSP) } & \multirow{2}{*}{ Total } & $\mathrm{p}$ \\
& baik & sedang & buruk & & \\
\hline \multirow{2}{*}{ Laki-laki } & 6 & 35 & 52 & 93 & 0,01 \\
& $6,5 \%$ & $37,6 \%$ & $55,9 \%$ & $100 \%$ & \\
Perempuan & 30 & 57 & 170 & 257 & \\
& $11,7 \%$ & $22,2 \%$ & $66,1 \%$ & $100 \%$ & \\
Total & 36 & 92 & 222 & 350 & \\
& $10,3 \%$ & $26,3 \%$ & $63,4 \%$ & $100 \%$ & \\
\hline
\end{tabular}

Analisis lanjut mendapatkan $\mathrm{p}=0,01$ yang berarti bahwa ada hubungan antara jenis kelamin dengan kontrol glikemik DM tipe 3
Tabel 5. Hubungan Antara Wilayah dengan kontrol glikemik DM tipe 2 berdasarkan pemeriksaan Kadar HbA1c (NGSP)

\begin{tabular}{|c|c|c|c|c|c|}
\hline \multirow{2}{*}{$\begin{array}{c}\text { Jenis } \\
\text { Kelamin }\end{array}$} & \multicolumn{3}{|c|}{ kadar HbA1c (NGSP) } & \multirow{2}{*}{ Total } & \multirow{2}{*}{$\mathrm{p}$} \\
\hline & baik & sedang & buruk & & \\
\hline \multirow{2}{*}{ Kota } & 27 & 50 & 138 & 215 & \multirow[t]{6}{*}{0,08} \\
\hline & $12,6 \%$ & $23,3 \%$ & $64,2 \%$ & $100 \%$ & \\
\hline \multirow{2}{*}{ Kabupaten } & 9 & 42 & 84 & 135 & \\
\hline & $6,7 \%$ & $31,1 \%$ & $62,2 \%$ & $100 \%$ & \\
\hline \multirow{2}{*}{ Total } & 36 & 92 & 222 & 350 & \\
\hline & $10,3 \%$ & $26,3 \%$ & $63,4 \%$ & $100 \%$ & \\
\hline
\end{tabular}

Analisis lanjut mendapatkan $\mathrm{p}=0,08$ yang berarti bahwa tidak ada hubungan antara wilayah dengan kontrol glikemik DM tipe 2.

Tabel 6. Hubungan antara Kadar Kolesterol, Trigliserida, HDL, LDL dengan kontrol glikemik DM tipe 2 berdasarkan pemeriksaan Kadar HbA1c (NGSP)

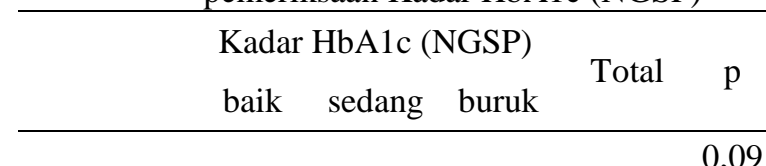

Kolesterol

0,09

\begin{tabular}{|c|c|c|c|c|c|}
\hline \multirow[t]{2}{*}{ Normal } & 18 & 47 & 86 & 151 & \\
\hline & $11,9 \%$ & $31,1 \%$ & $57,0 \%$ & $100 \%$ & \\
\hline \multirow{2}{*}{$\begin{array}{l}\text { Tidak } \\
\text { normal }\end{array}$} & 18 & 45 & 136 & 199 & \\
\hline & $9,0 \%$ & $22,6 \%$ & $68,3 \%$ & $100 \%$ & \\
\hline \multirow{2}{*}{ Total } & 36 & 92 & 222 & 350 & \\
\hline & $10,3 \%$ & $26,3 \%$ & $63,4 \%$ & $100 \%$ & \\
\hline Trigliserida & & & & & 0,000 \\
\hline \multirow[t]{2}{*}{ Normal } & 26 & 60 & 97 & 183 & \\
\hline & $14,2 \%$ & $32.8 \%$ & $53,0 \%$ & $100 \%$ & \\
\hline \multirow[t]{2}{*}{$\begin{array}{l}\text { Tidak } \\
\text { Normal }\end{array}$} & 10 & 32 & 125 & 167 & \\
\hline & $6,0 \%$ & $19,2 \%$ & $74,9 \%$ & $100 \%$ & \\
\hline \multirow[t]{2}{*}{ Total } & 36 & 92 & 222 & 350 & \\
\hline & $10,3 \%$ & $26,3 \%$ & $63,4 \%$ & $100 \%$ & \\
\hline HDL & & & & & 0,06 \\
\hline \multirow[t]{2}{*}{ Normal } & 31 & 77 & 183 & 291 & \\
\hline & $10,7 \%$ & $26,5 \%$ & $62,9 \%$ & $100 \%$ & \\
\hline \multirow[t]{2}{*}{$\begin{array}{l}\text { Tidak } \\
\text { Normal }\end{array}$} & 5 & 15 & 39 & 59 & \\
\hline & $8,5 \%$ & $25,4 \%$ & $66,1 \%$ & $100 \%$ & \\
\hline Total & 36 & 92 & 222 & 350 & \\
\hline LDL & & & & & 0,08 \\
\hline \multirow[t]{2}{*}{ Normal } & 31 & 82 & 189 & 302 & \\
\hline & $10,2 \%$ & $27,2 \%$ & $62,6 \%$ & $100 \%$ & \\
\hline \multirow[t]{2}{*}{$\begin{array}{l}\text { Tidak } \\
\text { Normal }\end{array}$} & 5 & 10 & 33 & 48 & \\
\hline & $10.4 \%$ & $20,8 \%$ & $68,8 \%$ & $100 \%$ & \\
\hline \multirow[t]{2}{*}{ Total } & 36 & 92 & 222 & 350 & \\
\hline & $10,3 \%$ & $36,3 \%$ & $63,4 \%$ & $100 \%$ & \\
\hline
\end{tabular}


Hasil analisis didapatkan kontrol glikemik buruk adalah pada kadar kholesterol normal dan tidak normal, Analisa lanjut pada kadar kolesterol mendapatkan $\mathrm{p}=0,09$ yang berarti bahwa tidak ada hubungan yang signifikan antara kadar kolesterol dengan kontrol glikemik DM tipe 2

Hasil analisis pada kadar trigliserida mendapatkan bahwa sebagian besar responden dengan kontrol glikemik baik adalah orang dengan kadar trigliserida normal, responden dengan kontrol glikemik sedang adalah orang dengan kadar trigliserida normal, sedangkan kontrol glikemik buruk adalah orang dengan kadar trigliserida tidak normal. Analisis lanjut mendapatkan $\mathrm{p}=0,000$ yang berarti bahwa ada hubungan signifikan kontrol glikemik DM tipe 2 dengan kadar trigliserida.

Hasil analisis pada kadar HDL mendapatkan bahwa sebagian responden dengan kadar HDL normal sedang kontrol glikemik DM tipe 2 dengan kategori buruk. Analisis lanjut mendapatkan $\mathrm{p}=0,6$ yang berarti bahwa tidak ada hubungan yang signifikan antara kadar HDL dengan kontrol glikemik DM tipe 2

Hasil analisis pada kadar LDL mendapatkan bahwa sebagian besar responden yang mempunyai nilai HbAlc berdasarkan NGSP dalam kategori diabetes adalah yang memeliki kadar LDL Normal. Analisis lanjut mendapatkan $\mathrm{p}=0,8$ yang berarti bahwa tidak ada hubungan yang signifikan antara kadar LDL dengan nilai HbA1c berdasarkan NGSP

\section{Pembahasan}

Penyakit Diabetes Melitus didiagnosa selain dengan pemeriksaan gula darah juga dengan pemeriksaan HbA1c (ADA, 2020). Selain untuk mendiagnosa DM, pemeriksaan HbA1c digunakan sebagai kontrol untuk melihat baik buruknya pengelolaan DM tipe 2 (Perkeni, 2015).

Kriteria kontrol glikemik dari pemeriksaan HbA1c meliputi Kontrol baik (< 7,0\%) Kontrol sedang (7 \%-8,0 \%) Kontrol buruk $(>8,0 \%)$ (Perkeni, 2019)

Beberapa faktor yang mempengaruhi penyakit DM diantaranya yang berhubungan dengan karaktersitik responden. Orang dewasa lebih bersiko menderita DM dibanding dengan usia remaja (WHO, 2016), sementara berdasarkan data riskesdas tahun 2018 menunjukan usia 65-74 lebih banyak menderita DM (Kemenkes, 2018).
Hasil penelitian menunjukan bahwa dari masing-masing responden yang di ukur berdasarkan usia penderita diabetes banyak terjadi pada usia 30-40 tahun dimana dari 9 responden yang melakukan pemeriksaan 18,2\% normal, $9,1 \%$ prediabetes dan $72 \%$ diabetes, sementara dari responden 61-70 tahun dari 124 responden $12,3 \%$ normal, $32 \%$ prediabetes, dan $55,7 \%$ diabetes.

Dari hasil penelitian terlihat adanya pergeseran dari umur penderita DM dari usia yang relatif tua ke usia yang lebih muda, faktor resiko dari pola konsumsi makanan dan gaya hidup menjadi pemicu perubahan tersebut, berdasarkan penelitian $\mathrm{T}$ syarifah tahun 2016 didapatkan $54 \%$ masyarakat indonesia usia remaja mengkonsumi makanan fast food non tradisional, dan mengalami berat badan lebih $41,7 \%$, obesitas $37,5 \%$ dan hanya $20,8 \%$ yang BB normal (Syarifah, 2016).

Pada suatu penelitian didapatkan bahwa kandungan energi dari fast food berkisar 236,5 $\mathrm{kkal} / \mathrm{hari}$ sampai dengan 3215,1 kkal/hari, sementara dengan konsumsi asupan energi $187 \mathrm{kkal} / \mathrm{hari}$ dari fast food bersiko menyebabkan obesitas pada remaja (Bonita, 2016). Sebuah penelitian menunjukkan bahwa konsumsi tinggi lemak pada western fast food berkaitan dengan peningkatan risiko obesitas, jantung, dan penyumbatan pembuluh darah (Widya, 2014). Dalam suatu penilitian didapatkan bahwa kandungan serat pada western fast food maupun traditional fast food tergolong sangat rendah. Misalnya pada $100 \mathrm{~g}$ fried chicken memiliki kandungan serat $0,9 \mathrm{~g}$, chicken nugget, hot and spicy chicken, original chicken, dan chicken fillet memiliki kandungan serat $0 \mathrm{~g}$ (Mc Donald, 2016)

Serat tinggi pada makanan ada kaitnya dengan penyakit DM, pada suatu penilitian didipatkan bahwa ada hubungan yang bermakna pada antara diet tinggi serat dengan kadar HbA1c pada penderita DM, dimana pada responden diet tinggi serat didapatkan hasil kontrol HbA1c yang baik (Harum, 2013).

Sementara jenis kelamin perempuan lebih banyak menderita DM dibandingkan yang berjenis laki laki, hasil ini sesuai dengan penelitian Azmi (2014) dan hasil riskesdas tahun 2018 (Kemenkes, 2018).

Dari uji korelasi didapatkan ada hubungan antara kontrol glikemik DM tipe 2 dengan profil lipid khususnya dengan nilai trigiserida, pada penelitian terdahulu didapatkan adanya hubungan antara peningkatan kadar trigliserida dengan kontrol buruk pada penderita DM tipe 2 (Zulfachmi, 2015). Adanya 
hubungan yang signifikan antara $\mathrm{HbA1c}$ dan kadar Trigliserida juga di dapatkan dari penelitian Rheza (2014). Namun penlitian yang dilakukan oleh Dharmasinti dkk (2016) menunjukan hubungan yang tidak signifikan antara kadar $\mathrm{HbA} 1 \mathrm{c}$ dengan kadar trigliserida

Zulfachmi menyororti hubungan peningkatan trigliserida dengan peningkatan kadar HbA1c sebagai kontrol buruk glikemik pada pasien DM tipe 2, sementara itu Rheza mengaitkan pada teori pathogensis DM tipe 2 fase lanjut, dimana pada fase ini kelebihan glukosa dalam darah disimpan dalam bentuk lemak, khususnya trigliserida. Sehingga jika kendali glikemik buruk, akan menimbulkan peningkatan kadar glukosa dalam darah. Selanjutnya glukosa diubah menjadi trigliserida, sehingga terjadi peningkatan kadar trigliserida (Drecole, 2019)

Teori menyebutkan bahwa penyakit DM dapat mempengaruhi peningkatan kadar lipid dalam darah, khususnya kholesterol dan trigliserida hal ini diakibatkan adanya perubahan metabolisme profil lipid dan merupakan faktor resiko dari kardiovaskuler (Shoback, 2018). Penyakit kardiovaskuler timbul karena adanya pembentukan arterosklerosis, dimana percepatan munculnya arterosklerosis salah satunya dipacu adanya dislipidemia (Pujari, 2013)

Peningkatan profil lipid erat kaitnya dengan adanya resistensi insulin yang menyebabkan lipolisis yang meningkat dan lipogenesis yang berkurang pada sel lemak, sehingga dapat menyebabkan peningkatan kadar gula dalam darah (Perkeni, 2019)

Sel lemak dalam tubuh berfungsi untuk menyimpan lemak khususnya trigliserida. Insulin akan membantu perubahan glukosa menjadi lemak melalui proses lipoginesis, Lipoprotein merupakan suatu senyawa pembawa trigliserida dan lemak yang lain untuk diedarkan ke seluruh tubuh. (Wardaini, 2012).

Triglsierida selain berasal dari kandungan dalam makanan yang dikonsumsi juga terbentuk dari adanyanya glikolisis, tingginya gula akan menyebabkan peningkatan kadar trgliserida karena proses glikolisis, yang disimpan dalam sel lemak dalam tubuh. (Wahyuni, 2014)

Kesimpulan dari hasil penelitian adalah terdapat hubungan yang bermakna jenis kelamin terhadap kontrol glikemik DM tipe 2, dan adanya korelasi antara kontrol glikemik DM tipe 2 berdasarkan interpretasi hasil pemeriksaan trigliserida.
Peningkatan kadar HbA1c berkaitan erat dengan adanya gangguan cardiovaskuler. Beberapa penelitian mendapatkan adanya hubungan yang signifikan antara adanya peningkatan kadar $\mathrm{HbA1c}$ dengan Sindrom koroner akut, gagal jantung, pankratsitis dan pasien pasca operasi baypass. Perlu diperhatikan pada penderita DM terhadap pola diet dan adanya peningkatan nilai profil lipid, khusunya kadar trigliserida karena peningkatan kadar trigliserida erat kainya dengan adanya gangguan kardiovaskuler, yang tentunya akan berakibat pada kompliasi gangguan jantung, ginjal dan berbagai organ vital lainnya.

Perlunya dikaji terkait perubahan karakteristik khususnya umur, bahwa usia muda saat ini juga berpotensi terkena penyakit DM, sehingga kebiasaan, pola hidup serta aktivitas menjaga kesehatan fisik untuk tetap ideal mampu menjadi kebiasaan baru sebagai upaya mencegah tejadinya penyakit DM secara dini.

\section{Daftar Pustaka}

Azmi Nur Rabrusun. 2014. hubungan antara umur dan indeks massa tubuh dengan kejadian diabetes mellitus tipe 2 di poliklinik interna blu rsup prof. dr. r. d. kandou manado

Budiman, Rosmariana Sihombing, Pramita Pradina. 2015. hubungan dislipidemia, hipertensi dan diabetes melitus dengan kejadian infark miokard akut

Diah Dharma Santhi, I Wayan Putu Sutirta Yasa, A A Gd Sudewa Djelantik. 2016. Profil Lipid Pada Penderita Diabetes Mellitus Tipe 2 Di RSUP. Sanglah Denpasar

Dolores Shoback. 2018. Greenspan's Basic \& Clinical Endocrinology

Ika Malia Bonita, Deni Yudi Fitrianti. 2016. konsumsi fast food dan aktivitas fisik sebagai faktor risiko kejadian overweight pada remaja stunting smp

Indonesian Jurnal. 2016. clinical pathology and medical laboratory

Indranila KS. 2017. glycated hemoglobin a1c as a biomarker predictor for diabetes mellitus, cardiovascular disease and inflammation 
Irmayanti, Arta Farmawati, Martalena Br Purba. 2019 'distribusi dan faktor-faktor yang berhubungan dengan kadar hemoglobin alc (hba1c) pada subjek dewasa indonesia', Gizi Indonesia, 42(1), p. 43. doi: $10.36457 /$ gizindo.v42i1.282

Kemenkes (2018a) 'Hasil Utama Riset Kesehatan Dasar (RISKESDAS)', Journal of Physics A: Mathematical and Theoretical, 44(8), pp. 1-200. doi: $10.1088 / 1751-8113 / 44 / 8 / 085201$.

Kemenkes RI. (2018b). Riskesdas 2018 Provinsi Lampung. Kementerian Kesehatan Republik Indonesia.

Mc. Donalds. McDonalds USA Nutrition Facts for Popular Menu Items. 2015

Perkeni (2015) 'Pedoman pengelolaan dan pencegahan diabetes melitus tipe 2 dewasa di Indonesia 2015', Perkumpulan Endokrinologi Indonesia.

Perkeni (2019) 'Pedoman pengelolaan dan pencegahan diabetes melitus tipe 2 dewasa di Indonesia 2019',.

Pujari, S. Subhash. 2013. HbA1c as marker of dyslipidemia in type 2 diabetes mellitus patients.Sch.J.App.Med.Sci.1(6) : 728731

Putri Nur Rahayu, Anik Handayati, Suhariyadi. (2020). hubungan kadar gula darah puasa dan profil lipid pada penderita diabetes melitus tipe 2 dengan kejadian stroke iskemik di rsud r.a basoeni mojokerto

Rheza Priyadi, Made Ratna Saraswati. 2014. hubungan antara kendali glikemik dengan profil lipid pada penderita diabetes melitus tipe 2

Wahyuni, S. 2014. Buku ajar Metabolisme biokimia

T Syarifah Latifah Hanun, Ari Pristiana Dewi, Erwin. 2016. hubungan antara pengetahuan dan kebiasaan mengkonsumsi fast food dengan status gizi pada remaja
Wardini, L. (2012), Hubungan Kadar Trigliserida Puasa Dengan Kejadian Stroke Iskemik, Fakultas Kedokteran Universitas Sumatra Utara, Medan

WHO (2016) 'Global Report on Diabetes', Isbn, 978, pp. 6-86. Available at: http://www.who.int/about/licensing/.

Widya R, Dian H. Different Recipes and Energy Density of Indonesia Fast Food on Percentage of Indonesian Daily Value. Symbiosis Online Publishing 2014;1(2):1-5

Zulfachmi Wahab, Andra Novitasari, Nur Fitria W Profil Lipid sebagai Kontrol Glikemik pada Pasien Diabetes Mellitus Tipe II 